University of Minnesota Morris Digital Well

University of Minnesota Morris Digital Well

$5-2006$

\title{
Late Pleistocene climate inferred from the reconstruction of the Taylor River glacier complex, southern Sawatch Range, Colorado
}

Keith A. Brugger

University of Minnesota, Morris

Follow this and additional works at: https://digitalcommons.morris.umn.edu/geol_facpubs

Part of the Geology Commons, and the Glaciology Commons

\section{Recommended Citation}

Brugger, K.A., 2006. Late Pleistocene climate inferred from the reconstruction of the Taylor River Glacier Complex, southern Sawatch Range, Colorado. Geomorphology, v. 75, 318-329.

This Article is brought to you for free and open access by the Faculty and Staff Scholarship at University of Minnesota Morris Digital Well. It has been accepted for inclusion in Geology Publications by an authorized administrator of University of Minnesota Morris Digital Well. For more information, please contact skulann@morris.umn.edu. 


\title{
Late Pleistocene Climate Inferred from the Reconstruction of the Taylor River Glacier Complex, Southern Sawatch Range, Colorado
}

\section{Keith A. Brugger ${ }^{1}$}

Geology Discipline, University of Minnesota, Morris, Morris, MN 56267, U.S.A.

\begin{abstract}
Ice surface topography of a late Pleistocene glacier complex, herein named the Taylor River Glacier Complex (TRGC), was reconstructed on the basis of detailed mapping of glacial landforms combined with analyses of aerial photos and topographic maps. During the last glacial maximum (LGM) the TRGC covered an area of $215 \mathrm{~km}^{2}$ and consisted of five valley or outlet glaciers that were nourished by accumulation in cirques basins and/or upland ice fields.
\end{abstract}

Equilibrium-line altitudes (ELAs) for the glaciers of the TRGC were estimated using the accumulation-area ratio method, assuming that ratio to be $0.65 \pm 0.05$. ELAs thus derived ranged from about 3275 to $3400 \mathrm{~m}$, with a mean of $3340 \pm 60 \mathrm{~m}$. A degree-day model (DDM) was used to infer the climatic significance of the LGM ELA. With no appreciable differences in precipitation with respect to modern climate, the ELA implies that mean summer temperatures during the LGM were $\sim 7.6^{\circ} \mathrm{C}$ cooler than today. The DDM was also used to determine the temperatures required to maintain steady-state mass balances for each of the reconstructed glaciers. The required reductions in summer temperature vary little about a mean of $7.1^{\circ} \mathrm{C}$. The sensitivity of these results to slight $( \pm 25 \%)$ changes assumed for LGM precipitation are less than $\pm 0.5^{\circ} \mathrm{C}$. Even under an LGM climate in which precipitation is assumed to be substantially different $( \pm 50 \%)$ than the present, mean summer temperatures must be on the order of 7.0 to $8.5^{\circ} \mathrm{C}$ lower to depress equilibrium lines to LGM altitudes. The greater sensitivity of the ELA to changes in temperature suggests that glaciation in the region was driven more by decreases in summer temperature rather than increases in precipitation.

Keywords: glaciation; Pleistocene climate; equilibrium-line altitudes; Sawatch Range; Colorado

*Email Address: bruggeka@mrs.umn.edu 


\section{Introduction}

Quantitative estimates of late-Quaternary climate in the Colorado Rocky Mountains have been obtained using a variety proxies, including pollen spectra and timberline fluctuations (e.g. Maher, 1972; Carrera et al., 1984; Vierling, 1998), fossil beetle assemblages (e.g., Short and Elias, 1987; Elias, 1996), and analyses of late-glacial snowline depression (Leonard, 1984; 1989). The majority of these have been made for the Front Range and San Juan Mountains (Fig. 1). Only a few investigations (e.g., Markgraf and Scott, 1981; Fall, 1997; Brugger and Goldstein, 1999) have sought to document in a similar way paleoclimate in the interjacent Sawatch Range. Moreover, many climate proxies for the broader region do not extend back to the last glacial maximum (LGM, ca $21 \mathrm{ka})$.

The purpose of this paper is to present several inferences regarding paleoclimate during the LGM based on a reconstruction of the Taylor River Glacier Complex. The approach taken here uses a degree-day model to simulate variations in equilibrium-line altitudes and/or glacier mass balances brought about by changes in temperature and precipitation. This analysis compliments an earlier investigation in the study area by Brugger and Goldstein (1999).

\section{Study area}

The Taylor River drainage lies between the crest of the southern Sawatch Range to the east and the western flank of the Elk Mountains in central Colorado (Fig. 1). The Sawatch Range is a fault-bounded block consisting largely of Precambrian crystalline and Tertiary (mostly Oligocene) intrusive rocks uplifted during the Late Mesozoic-Early Tertiary Laramide Orogeny (Tweto, 1983; 1987). Thrust-faulted Paleozoic and Mesozoic sedimentary sequences form the core of the Elk Mountains and underlie a large portion of the upper Taylor River drainage. Tertiary intrusives also occur here as large plutonic bodies exhumed during post-Laramide uplift (Tweto et al., 1978; Fridrich et al., 1998). The lower reach of the Taylor River is deeply incised into Precambrian gneisses and granitic intrusive rocks. Extensive modification from Tertiary uplift and stream dissection and Pleistocene glaciation has resulted in a landscape of high relief where 
alpine peaks (many exceeding $4000 \mathrm{~m}$ ) are separated by deeply incised valleys or parks (broad treeless basins).

Two glaciations are recognized in the study area, which Brugger and Goldstein (1999) referred to as the younger Taylor River and older Cow Creek glaciations. Well-preserved, sharpcrested, hummocky terminal and lateral moraine complexes delineate the extent of glaciers in the Taylor River drainage during the younger glaciation (Fig. 2). In contrast, evidence for the extent of the Cow Creek glaciation is scant. In the few places where they exist, the older moraines tend to be relatively massive but subdued, and are only slightly downvalley of the younger moraines. Their absence in other places may perhaps suggest that advances of subsequent Taylor River-age glaciers were at least comparable to their Cow Creek counterparts (obliterating or burying the older moraines).

Eight cosmogenic ${ }^{10} \mathrm{Be} /{ }^{36} \mathrm{Cl}$ exposure ages have been obtained from five large $(>1.5 \mathrm{~m})$ boulders on a Taylor River-aged terminal moraine complex in the main valley (Fig. 2). Zeroerosion ages corrected for sample depth and topographic shielding range from $16.3 \pm 1.6$ to $22.2 \pm$ $2.8 \mathrm{ka}$ (Brugger, in prep.) using the production rates (corrected for latitude and altitude) of Gosse and Stone (2001) for ${ }^{10} \mathrm{Be}$ and Gosse and Phillips (2001) for ${ }^{36} \mathrm{Cl}$. Additional corrections for erosion (assumed to be $\sim 1 \mathrm{~mm} \mathrm{ka}^{-1}$ based on the work of Benedict (1993) for example) and snow shielding change these ages only by a few $(\leq 3)$ percent. Thus the Taylor River glaciation appears to be correlative to other advances during the LGM in the central Rocky Mountain region (e.g. Gosse et al., 1995; Benson et al., 2004; 2005).

No absolute ages have been obtained for moraines of Cow Creek age. On the basis of morphostratigraphy, moraines of this glaciation have been correlated (Brugger and Goldstein, 1999) to those of Bull Lake age in the Wind River Range, Wyoming, and regional equivalents. Initial cosmogenic ages on the type deposits (Phillips et al., 1997; Chadwick et al., 1997) suggested that the Bull Lake glaciation began prior to $130 \mathrm{ka}$ and lasted until $\sim 95 \mathrm{ka}$. Phillips et al. (1997) and Chadwick et al. (1997), noting the uncertainties associated with these ages, concluded that glacier expansion during the Bull Lake glaciation could have occurred in either 
marine isotope stage (MIS) 5d (117-103 ka) or at the end of MIS 6 (>127 ka). Recently, however, Sharp et al. (2003) obtained a ${ }^{230} \mathrm{Th} / \mathrm{U}$ date of $150 \mathrm{ka}$ for glaciofluvial terraces of Bull Lake age, placing that glaciation more firmly in MIS 6. More locally, Benson et al. (2004) have dated Bull Lake equivalents in north-central Colorado using ${ }^{36} \mathrm{Cl}$, reporting one age that corresponds to MIS 6 and several younger ages corresponding broadly to MIS 5. They conclude that the latter were most probably deposited during MIS 6 and reconcile the younger dates as being a consequence of snow and sediment shielding, and ${ }^{36} \mathrm{Cl}$ leakage.

\section{The Taylor River Glacier Complex}

The Taylor River Glacier Complex (Fig. 3) consisted of large valley glaciers whose accumulation areas coalesced with upland ice fields centered on interfluves. The reconstruction depicted in Figure 3 is based on the extent and upper limit of ice determined from detailed field mapping and analyses of both topographic maps and aerial photographs. The extent of glacial ice in valleys and cirque basins was, to varying degrees, delineated using moraine geometry, the distributions of erratic boulders, and the upper limits of glacial erosion. Ice-covered upland surfaces are characterized by features that indicate active and presumably warm-based ice. These include: polished, striated, and/or grooved bedrock slabs, often showing abundant crescentic gouges, and lunate fractures; streamlined bedrock ridges (whalebacks), including roches moutonnées; shallow bedrock -floored scour basins fronted by low riegels (Fig. 4a); transverse rock bars of low relief typically showing a distinct asymmetry (Fig. 4b); and small troughs through which ice flowed and merged with contiguous valley glaciers (Fig. 4c). On a larger scale, ice-covered upland landscapes tend to exhibit a more subdued, rounded topography and lack craggy areas. This is particularly true of areas presumed to have been under major ice divides (Fig. 4b).

Ice surface contours for the reconstruction of the TRGC are fairly well constrained by the elevations of ice margins, and local ice flow directions indicated by bedrock topography and larger-scale streamlined features. Small adjustments to the contours were made iteratively to insure that ice thickness and surface slopes along major flow lines yielded basal shear stresses that 
fell within 50-150 kPa (Paterson, 1994). It should also be noted that the reconstruction shown in Figure 3 assumes that advances of all valley and outlet glaciers to their maximum extents were roughly synchronous.

In its LGM configuration, the Taylor River Glacier Complex (TRGC) covered an area of about $215 \mathrm{~km}^{2}$, of which the two principal valley glacier systems comprised $\sim 170 \mathrm{~km}^{2}$ and four upland ice fields $\sim 45 \mathrm{~km}^{2}$. Ice elevations ranged from $2935 \mathrm{~m}$ to $4090 \mathrm{~m}$. Maximum ice thickness in the Taylor valley (Fig. 3) exceeded $350 \mathrm{~m}$ while that in the Spring Creek was $200 \mathrm{~m}$. The maximum thickness of upland ice is, however, difficult to estimate precisely because of the inability to assign an upper limit of glaciation (e.g. lack of nunataks) in many areas in which the ice fields existed. Based on the reconstruction of the TRGC in those areas where the upper limit is better constrained, the thickness of upland ice was probably less than $100 \mathrm{~m}$.

Assuming a mean equilibrium-line altitude (ELA) of $~ 3380 \mathrm{~m}$ for the entire TRGC (discussed subsequently), upland ice fields account for nearly a quarter of the accumulation area. For the larger valley system $\left(\sim 175 \mathrm{~km}^{2}\right)$ that terminated in the Taylor River Lobe (Fig. 3), upland ice contributed about $19 \mathrm{~km}^{2}$ to, or $\sim 10 \%$ of the accumulation area. In contrast, upland ice made up slightly less than $20 \%$ of the total $27 \mathrm{~km}^{2}$ of the glacier area that fed the Spring Creek Lobe, but constitutes more than $45 \%$ of its accumulation area. Three small outlet lobes, referred to here as Rocky, Trail Creek, and Bushwhack Glaciers, are supported solely by upland ice. The Mysterious Ice Field in particular (Fig. 3) might thus be expected to have played a dominant role in the dynamic behavior and response to climate change of its three outlet glaciers and a significant role in that of the Spring Creek Lobe.

Brugger and Goldstein (1999) hypothesized that the ice fields were transient rather than longlived components of the TRGC, speculating that upland ice appeared late during the last glaciation and disintegrated early during subsequent deglaciation. They cited a bog bottom date of $15.6 \pm$ $0.25{ }^{14} \mathrm{C}$ ka (PITT-0120, 18,500 - 19,440 cal yr B.P.; Stuiver and Reimer, 1993) obtained in an area that would have been under the accumulation area of the Mysterious Ice Field (Fig. 3), as a minimum date for deglaciation of upland surfaces. The cosmogenic surface-exposure ages 
reported here are interpreted as representing an interval of moraine building from $\sim 22.5$ to $\sim 16.5$ ka (Brugger, in prep.). Thus it would appear that the ice fields had already disintegrated as the Taylor River Lobe, and presumably the other larger valley glaciers, were at or near their maximum extents. Furthermore if upland ice, the sole accumulation area for the outlet glaciers, disappeared between about 19.4 and $18.5 \mathrm{ka}$, this would imply those glaciers would have begun to retreat prior to this, and hence long before ice in the main valleys.

Field evidence corroborates the transient behavior and climatic sensitivity of the upland ice components of the TRGC. Specifically, the Rocky Brook, Trail Creek, and Bushwhack valleys are "V-shaped," and unlike the main valleys lack any significant recessional moraines. Valley shape could in part reflect the minimal erosional capability given the thinness of these outlet glaciers, lithologies of greater resistance to erosion, or a shorter duration of ice cover. Ice thicknesses ( 100-150 m), surface slopes, and presumably mass balances (and therefore most likely basal ice velocities) were, however, comparable to those of other smaller glaciers that existed elsewhere in the study area which were effective in eroding "U-shaped" valleys. In fact, evidence for active erosion in the Rocky Brook, Trail Creek, and Bushwhack valleys can be found in the form of streamlined bedrock and roches moutonées. Likewise the bedrock here is generally the same as elsewhere. Hence the limited modification of valley cross-sections is thought to be due instead to a relatively short interval of glacial erosion.

The relative absence of recessional moraines in the valleys of the outlet glaciers could be attributed to a limited source(s) of debris, especially that derived supraglacially owing to the lack of cirque headwalls and valley sides in these systems. The large terminal moraine complex built by the Trail Creek glacier, for example, would indicate otherwise. Ice retreat in the Rocky Brook, Trail Creek, and Bushwhack valleys thus appears to have been rather continuous. This furthermore implies these glaciers, supported solely by the Mysterious Ice Field, only achieved steady state when equilibrium lines were at their lowest elevation, that is during the LGM. Preliminary results of numerical flow modeling (Brugger, 2003) also show this "conditional steady-state" of upland systems. This is not surprising in view of the fact that the catchment areas of these systems do not benefit from topographic sheltering and were therefore subjected to 
increased ablation and reduced snow accumulation due to wind deflation. Nor do the catchment areas extent to high elevations. In order for these system to have developed, ELAs must be low enough for snow to first persist on upland surfaces (most of which lie between 3400 and $3550 \mathrm{~m}$ a.s.1.), but then ultimately allow ice to thicken and expand, effectively growing the accumulation area. Modestly higher ELAs would either prevent the initial formation of extensive upland ice, or lead to its rapid demise.

\section{LGM ELAs of the Taylor River Glacier Complex}

ELAs for glaciers sourced from the TRGC were estimated using the now standard accumulation-area (AAR) method (Porter, 1975, Benn and Evans, 1998). While AAR values observed on modern glaciers generally vary between 0.50 and 0.80 (Meier and Post, 1962), values between 0.55 and 0.65 are typically used to determine ELAs for reconstructed glaciers (e.g., Porter, 1975; Meierding, 1982; Leonard, 1984; Torsnes et. al., 1993). There has been some concern, however, whether these values should be applied to glaciers having skewed area-altitude distributions (hypsometry) such as ice caps, and outlet and piedmont glaciers (Meier and Post, 1962; Pierce, 1979; Furbish and Andrews, 1984; Leonard, 1984; Nesje, 1992; Torsnes et. al., 1993; Brugger and Goldstein, 1999; Benn and Lehmkuhl, 2000). Nevertheless, AAR values of 0.60 to 0.70 have been used to estimate ELAs for outlet glaciers emanating from ice caps or plateau ice fields (e.g., Nesje and Dahl, 1991; Torsnes et. al., 1993; Lachniet and Seltzer, 2002; Ballantyne, 2002; Douglass et al.). A median value of $0.65 \pm 0.05$ is used here because the glaciers' hypsometries (Fig. 5) are not too dissimilar to those of valley glaciers (i.e., glacier area is essentially normally distributed). This value also conforms to that used previously by Brugger and Goldstein (1999) to determine paleo-ELAs for former valley glaciers in the Taylor River drainage (Fig. 2).

The cumulative-area distribution with elevation and resultant ELA for each of the glaciers of the TRGC are shown in Figure 5. ELAs vary from about 3275 to 3400 m, having a mean of 3340 $\pm 60 \mathrm{~m}$ (Table 1). The ELA for the TRGC taken as a whole (which is essentially an area-weighted average of the ELAs for individual glaciers) is $3380 \pm 25 \mathrm{~m}$. These estimates are also very 
consistent with a mean ELA of $3375 \pm 15$ m obtained by Brugger and Goldstein (1999) based on reconstructions of six other valley glaciers in the study area. No significant geographical trends in the elevations of equilibrium lines are evident within the Taylor River drainage, however, regionally (across $\sim 100 \mathrm{~km}$ ) ELAs rise to the east at a gradient of about $3.5 \mathrm{~m} \mathrm{~km}^{-1}$ (Brugger and Goldstein, 2000).

\section{Degree-day modeling and paleoclimate inferences}

The paleoclimatic significance of LGM ELAs of the Taylor River Glacier Complex can be examined using a simple degree-day model (DDM) in either of two approaches. The first seeks to estimate the changes in temperature and/or precipitation necessary to maintain an ELA whose altitude is known independently (e.g., by using the AAR method). Alternatively, the DDM can be used to find changes in temperature and/or precipitation required for steady-state mass balance of a glacier. Both approaches are used here.

\subsection{The degree-day model}

Details of the DDM will be presented elsewhere and therefore only a brief description of the model is given here. The specific net mass-balance $b_{n}$ at a elevation $z$ is

$$
b_{n}(z)=\int_{t}^{t_{2}} P_{x}(t, z)+M(t, z) d t
$$

where $\mathrm{M}(\mathrm{t}, \mathrm{z})$ is the rate of ice or snow melt (assumed here to be equivalent to ablation, that is refreezing of meltwater is ignored), $\mathrm{P}_{\mathrm{s}}(\mathrm{t}, \mathrm{z})$ is the rate of snow precipitation (accumulation) and $\mathrm{t}$ is time. The interval $t_{1}$ to $t_{2}$ represents the hydrologic year (October $1^{\text {st }}$ to September $30^{\text {th }}$ ). By definition $b_{n}=0$ at the equilibrium line.

In practice Equation (1) is numerically integrated and thus becomes

$$
b_{n}(z)=\sum_{m=1}^{12}\left[P_{x m}-\sum_{d=1}^{n} M_{d}\right]
$$


where $P_{s m}$ is the monthly snow precipitation, $\mathrm{M}_{\mathrm{d}}$ is the daily melt, and $\mathrm{n}$ is the number of days in month $\mathrm{m}$. (The daily versus monthly summation of temperatures and precipitation values, respectively, is an artifact of the temporal resolution of available climate data.) Daily melt is related to mean daily air temperature $T_{d}$ through a degree-day factor $d_{f}$, thus

$$
\begin{array}{cc}
\mathrm{M}_{\mathrm{d}}=\mathrm{d}_{\mathrm{f}} \mathrm{T}_{\mathrm{d}} & \mathrm{T}_{\mathrm{d}}>0{ }^{\circ} \mathrm{C} \\
\mathrm{M}_{\mathrm{d}}=0 & \mathrm{~T}_{\mathrm{d}} \leq 0{ }^{\circ} \mathrm{C} .
\end{array}
$$

Values of $\mathrm{d}_{\mathrm{f}}$ for ice and snow are taken here as $8.0 \pm 1.0$ and $4.0 \pm 1.0 \mathrm{~mm}$ w.e. (water equivalent) $\mathrm{d}^{-1}{ }^{\circ} \mathrm{C}^{-1}$ respectively, based on means values determined for relatively debris-free snow and ice on modern glaciers (e.g., Jóhannesson and others, 1995; Hock, 1999; Braithwaite and Zhang, 2000; among others). Monthly snow precipitation is

$$
\mathrm{P}_{\mathrm{sm}}=f\left(\mathrm{P}_{\mathrm{mod}}+\Delta \mathrm{P}\right)
$$

where $\mathrm{P}_{\text {mod }}$ is the modern mean monthly precipitation and $\Delta \mathrm{P}$ is the prescribed perturbation in precipitation. An empirically-derived, temperature-dependent partitioning function $f$ is used to determine that fraction of the monthly precipitation that falls as rain or snow (Brugger, in prep.). Initially $d_{f}$ for snow is used, but at that point in the modeled hydrologic year when melt exceeds snow accumulation it is replaced with that for ice. Mean daily air temperatures are assumed to vary sinusoidally about the mean annual temperature $T_{a}$

$$
\mathrm{T}_{\mathrm{d}}=\mathrm{A}_{y} \sin \left(\frac{2 \pi \mathrm{d}}{\lambda}-\phi\right)+\mathrm{T}_{\mathrm{a}}
$$

where $A_{y}$ is the amplitude of yearly temperature variations, $d$ is the Julian day, $\lambda$ is the period (365 d), and $\phi$ is the phase angle (taken here as $\sim 1.93$ rad so yearly maximum and minimum temperatures in the model match those observed). The amplitude is given by

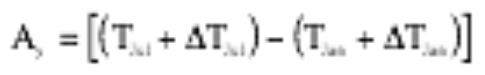

where $\mathrm{T}_{\mathrm{Jul}}$ and $\mathrm{T}_{\mathrm{Jan}}$ are the modern mean July and January air temperatures, respectively, and $\Delta \mathrm{T}_{\mathrm{Jul}}$ and $\Delta \mathrm{T}_{\mathrm{Jan}}$ are the prescribed temperature perturbations. 
Modern climate data used in the model is based on temperature and precipitation records from six meteorological stations within or immediately outside the study area (Fig.1, Table 1). The lengths of the climate records at these stations vary from more than 100 years at Gunnison to about 30 years at Independence Pass. Shorter records from two SNOTEL sites were also used to augment the precipitation data. For the shorter records, comparable longer-term temperature and precipitation means were obtained by imputation (Little and Rubin, 1987). Climate parameters from the Taylor Park station ( $2800 \mathrm{~m}$; Table 1$)$ were used as the datum in the model as it is located within the study area .

Using the modern precipitation gradient $\left(\sim 0.0059\right.$ m w.e. $\left.\mathrm{m}^{-1}, \mathrm{r}^{2}=0.96, \mathrm{p}<0.0005\right)$ and lapse rate for temperature $\left(\sim 0.0067{ }^{\circ} \mathrm{C} \mathrm{m}^{-1}, \mathrm{r}^{2}=0.64, \mathrm{p}<0.05\right)$, Equation (6) can be solved iteratively at different elevations yielding a specific net-balance curve $\left(b_{n}(z)\right.$ as a function of elevation) and an ELA (where $b_{n}=0$ ). Specific net-balances were thus calculated at $20 \mathrm{~m}$ intervals over an altitudinal range of 2800 to $4200 \mathrm{~m}$ which encompasses that of the TRGC. It should be noted that results of the modeling are not particularly sensitive to slightly different values of $\mathrm{d}_{\mathrm{f}}$. Typically the uncertainties in $\mathrm{d}_{\mathrm{f}}$ noted above $\left( \pm 1.0 \mathrm{~mm}\right.$ w.e. $\left.\mathrm{d}^{-1}{ }^{\circ} \mathrm{C}^{-1}\right)$ result in an uncertainty of $\pm 20 \mathrm{~m}$ in the altitude of the equilibrium line, or $\pm 0.3{ }^{\circ} \mathrm{C}$ in derived temperature estimates (Brugger, in prep.). Comparable uncertainties also result when the lapse rate is allowed to vary slightly.

Likewise small changes in seasonality (the difference between mean July and January temperatures) brought about by severely colder winters (cf. Elias, 1996) are inconsequential. The effect of having $\Delta \mathrm{T}_{\mathrm{Jan}}$ values two to four times the $\Delta \mathrm{T}_{\text {Jul }}$ values reported here is to only slightly lengthen the ablation season, forcing $\Delta \mathrm{T}_{\mathrm{Jul}}$ to be $\sim 0.5^{\circ} \mathrm{C}$ warmer. Thus the results presented here assume $\Delta \mathrm{T}_{\mathrm{Jul}}=\Delta \mathrm{T}_{\mathrm{Jan}}$ (i.e. a uniform temperature depression), which means $\Delta \mathrm{T}_{\text {jul }}$ is equivalent to the mean summer temperature depression, denoted $\Delta \mathrm{T}$.

The second approach to infer climate using the DDM is to vary $\Delta \mathrm{T}$ in order to find a specific net balance curve so that in conjunction with its area-altitude distribution a paleoglacier's net mass balance is 


$$
\mathrm{B}_{\mathrm{n}}=\int_{\mathcal{A}} \mathrm{b}_{\mathrm{n}} \mathrm{dA} \sim \sum_{i=1}^{k} \mathrm{~b}_{\mathrm{n}} \mathrm{A}=0
$$

where A is glacier area, and the subscript " $\mathrm{i}$ " denotes values for $\mathrm{k}$ number of discrete altitudinal intervals, and thus $b_{n}$ is the mean specific net-balance over $A_{i}$. Altitudinal intervals of $100 \mathrm{~m}$ were used here. Equation (7) imposes the condition that the glacier is in steady state with climate. This alternative also has an advantage because it explicitly considers the distribution of a glacier's area with elevation making it similar to the balance-ratio method of steady-state ELA determination (cf. Furbish and Andrews , 1984; Benn and Gemmell, 1997).

\subsection{Validity of the DDM}

The validity of the DDM was assessed by: (1) its ability to accurately simulate the evolution of modern snowpack as recorded at the SNOTEL sites; and (2) its prediction of modern regional ELA (MELA) or snowline. Using values for temperature and precipitation representative of existing climate (therefore $\Delta \mathrm{T}_{\mathrm{jul}}, \Delta \mathrm{T}_{\mathrm{jan}}=0, \Delta \mathrm{P}=1.0$ ) and $\mathrm{d}_{\mathrm{f}}$ for snow, simulated snowpack evolution is in excellent agreement with that observed at the Park Cone and Independence Pass sites (Fig. 6a and b). The minor discrepancies result from differences in the temporal resolution of the simulation (monthly) and observed (daily) evolution, and the regional nature of the derived altitudinal dependence of precipitation and temperature.

Degree-day modeling yields an estimate of $4100 \pm 75 \mathrm{~m}$ for modern regional snowline, which unfortunately cannot be directly compared to observed MELA or regional snowline because the latter are not known in the southern Sawatch Range. Instead, comparisons must be made to estimates of MELA obtained by other methods. The preferred alternative is based on the conclusions of Ohmura and others (1992) who found that climate at the ELA of modern glaciers falls within a well-defined envelope of temperature and precipitation. Using the temperature and precipitation gradients in the study area, elevations can be found that meet these requirements

(Fig. 6c). The MELA estimated in this way is between 4025 and $4330 \mathrm{~m}$, which is very consistent with the results of the DDM. 


\subsection{LGM climate inferred from modeling}

Assuming that LGM precipitation amounts and seasonal distribution were similar to those that characterize climate in the region today, the mean ELA of glaciers of the TRGC (3340 m) is achieved by a reduction of mean summer temperature by $\sim 7.6^{\circ} \mathrm{C}$ (Fig. 7). LGM climates in the central Rocky Mountains may, however, have been slightly drier than present (e.g., Thompson et al., 1993; Hostetler and Clark, 1997). To examine this possibility, and that of a slightly wetter LGM climate, precipitation was accordingly decreased or increased by $25 \%$. These scenarios can also be viewed as a sensitivity analysis to the potential influences of shifts in the seasonal distribution of precipitation (e.g., increasing total precipitation during the LGM embodies a scenario in which the total precipitation remained the same but a greater fraction fell during the winter). If LGM precipitation was $25 \%$ greater than it is today, summers would have had to have been $\sim 7.3{ }^{\circ} \mathrm{C}$ cooler to maintain the late glacial ELA (Fig. 7, Table 2). On the other hand, if precipitation was $25 \%$ less than it is today a cooling of $\sim 7.9 \mathrm{C}$ is implied.

The relative sensitivity of the LGM ELA to changes in both temperature and precipitation is further explored in Figure 8. For the simple analysis here, $3340 \mathrm{~m}$ is taken as the "target ELA." Figure 8 shows that even for rather substantial differences in precipitation that might have characterized LGM climate (say about $\pm 50 \%$ of modern), decreases in mean summer temperature of 7.0 to $8.3{ }^{\circ} \mathrm{C}$ are necessary to depress the ELA to the target value. Conversely, a more modest $\Delta \mathrm{T}$ of $-5^{\circ} \mathrm{C}$ would require more than a $350 \%$ increase in precipitation. This suggests that decreases in summer temperature rather than increases in precipitation were the primary climatic forcing that initiated glaciation in this region. Similar conclusions were reached by Leonard (1989), Hostetler and Clark (1997); and Brugger and Goldstein (1999).

Under precipitation conditions similar to the present, steady-state mass balances for the five glaciers of the TRGC would have been maintained by LGM $\Delta \mathrm{T}$ ranging from 6.7 to $7.5^{\circ} \mathrm{C}$ with a mean of $7.1^{\circ} \mathrm{C}$ (Table 2). For wetter or drier conditions (again $25 \%$ greater or less than modern) during the LGM, steady-state mass balance for the glaciers would have required only slightly different changes in mean summer temperature, about -6.7 and $-7.5^{\circ} \mathrm{C}$ respectively. 
The magnitude of LGM cooling $\left(\sim 7-8^{\circ} \mathrm{C}\right)$ suggested by the foregoing analyses is very consistent with those previously derived in both the study area and the broader central Rocky Mountain region. In particular, Brugger and Goldstein (1999) inferred a range of 7 to $9{ }^{\circ} \mathrm{C}$ for summer temperature depression in the study area based on the ELAs of six reconstruction valley glaciers (Fig. 2) and an analysis of climate at the equilibrium lines of modern glaciers. Using the DDM described here, Brugger (in prep.) found that $\Delta \mathrm{T}$ value of about $-7.5^{\circ} \mathrm{C}$ yielded the mean ELA of $3375 \mathrm{~m}$ independently estimated by Brugger and Goldstein (1999). Alternatively, he showed that steady-state mass balance for the six valley glaciers requires $\Delta \mathrm{T}$ values that lie between -6.6 and $-7.7^{\circ} \mathrm{C}$, the mean $\left(-7.1^{\circ} \mathrm{C}\right)$ corresponding to a steady-state ELA of $\sim 3400 \mathrm{~m}$. In an analysis of snowline depression in several ranges in Colorado, Leonard (1989) inferred that mean summer temperatures during the LGM were $\sim 8.5^{\circ} \mathrm{C}$ lower than present, and could have been as much as $13{ }^{\circ} \mathrm{C}$ cooler if the climate was appreciably drier. Regional climate modeling led Hostetler and Clark (1997) to conclude that LGM temperatures were $9-12{ }^{\circ} \mathrm{C}$ cooler in the middle and southern Rocky Mountains. Based on fossil beetle assemblages, Elias (1996) estimated that mean summer temperatures in the Rocky Mountains were depressed $10-12{ }^{\circ} \mathrm{C}$ during the LGM.

\section{Conclusions}

The Taylor River Glacier Complex developed from the coalescing of valley glacier systems with upland ice fields during the last glacial maximum. At its maximum extent, the TRGC covered an area of about $215 \mathrm{~km}^{2}$ and nourished five glaciers or outlet lobes of varying size. Using the AAR method the mean ELA of the five glaciers is estimated to have been $\sim 3340 \pm 60$ m. Degree-day modeling suggests that this ELA was maintained by a reduction of mean summer temperature by about $7.6^{\circ} \mathrm{C}$ under a scenario in which LGM precipitation was similar to that of modern climate. Somewhat wetter or drier LGM climate scenarios require similar temperature depressions (7.3 and $7.9^{\circ} \mathrm{C}$ respectively). Additional modeling suggests that steady-state mass balances of the glaciers would have required a comparable cooling of about $7.1{ }^{\circ} \mathrm{C}$, corresponding to a mean ELA of $3405 \pm 45 \mathrm{~m}$. The latter values are also not particularly sensitive 
to slight variations assumed for LGM precipitation. Degree-day modeling furthermore implies that glaciation in the region was caused more by cooler summer temperatures than by increases in precipitation.

\section{Acknowledgements}

Barry Goldstein cheerfully assisted in the field mapping, initiated numerous stimulating discussions, and provided many useful comments over the years in which this work was carried out. Thanks are also due to D. Kovanen, E. Leonard, and J. Munroe whose insightful reviews and constructive suggestions improved the manuscript. 


\section{References}

Ballantyne, C.K., 2002. The Loch Lomond Readvance on the Isle of Mull, Scotland: glacier reconstruction and paleoclimatic implications. J. Quat. Sci. 17, 759-771.

Benn, D.I., Evans, D.J.A., 1998. Glaciers and Glaciation. Arnold, London.

Benn, D.I., Gemmell, A.M.D., 1997. Calculating equilibrium-line altitudes of former glaciers: a new computer spreadsheet. Glacial Geology and Geomorphology http://ggg.qub.ac.uk/ggg/paper/full/1997/tn011997/tn01.htm.

Benn, D.I., Lehmkuhl, F., 2000. Mass balance and equilibrium-line altitudes of glaciers in highmountain environments. Quat. Int. 65/66, 15-29.

Benedict, J.B., 1993. Influence of snow cover upon rates of granodiorite weathering , Colorado Front Range, USA. Boreas 22, p. 87-92.

Benson, L., Madole, R., Phillips, W., Landis, G., Thomas, T., Kubik, P., 2004. The probable importance of snow and sediment shielding on cosmogenic ages of north-central Colorado Pinedale and pre-Pinedale moraines. Quat. Sci. Rev. 23, 193-206.

Benson, L., Madole, R., Landis, G., Gosse, J.C., 2005. New data for Late Pleistocene Pinedale alpine glaciation in southwestern Colorado. Quat. Sci. Rev. 24, 49-66.

Braithwaite, R.J., Zhang, Y., 2000. Sensitivity of mass balance of five Swiss glaciers to temperature changes assessed by tuning a degree-day model. J. Glaciol. 46, 7-14.

Brugger, K.A., 2002. Cosmogenic dating of glacial moraine sequences in the Taylor River Valley, southern Sawatch Range, Colorado. Geol. Soc. Amer. Abstr. Programs 34, A548.

Brugger, K.A., 2003. Climatic sensitivity of upland ice fields during the last glacial maximum in the Taylor River Valley, southern Sawatch Range, Colorado. Geol. Soc. Amer. Abstr. Programs 34 A542.

Brugger, K.A., Goldstein, B.S., 1999. Paleoglacier reconstruction and late-Pleistocene equilibrium-line altitudes, southern Sawatch Range, Colorado. In: Mickelson, D.M., Attig, J.W. (Eds.), Glacial Processes Past and Present: Geol. Soc. Amer. Spec. Pap. 337, 103-112.

Brugger, K.A., Goldstein, B.S., 2000. Regional climatic trends during the last glacial maximum, Sawatch Range and Elk Mountains, Colorado. Geol. Soc. Amer. Abstr. Programs 32, A18.

Carrara, P.E., Madole, W.N., Meyer, R.L., Robinson, S.W., 1984. Deglaciation and postglacial timberline in the San Juan Mountains. Quat. Res. 21, 42-56.

Chadwick, O.A., Hall, R.D., Phillips, F.M., 1997. Chronology of Pleistocene glacial advances in the central Rocky Mountains. Geol. Soc. Amer. Bull. 109, 1443-1452.

Douglass, D.C., Singer, B.S., Kaplan, M.R., Ackert, R.P., Mickelson, D.M., Caffee, M.W., 2005. Evidence of early Holocene glacial advances in southern South America from cosmogenic surface-exposure dating. Geol. 33, 237-240.

Elias, S.A., 1996. Late Pleistocene and Holocene seasonal temperatures reconstructed from fossil beetle assemblages in the Rocky Mountains. Quat. Res. 46, 311-318.

Fall, P.L., 1997. Timberline fluctuations and late-Quaternary paleoclimates in the southern Rocky Mountains, Colorado. Geol. Soc. Amer. Bull. 109, 1306-1320.

Furbish, D.J., and Andrews, J.T., 1984. The use of hypsometry to indicate long-term stability and response of valley glaciers to changes in mass transfer. J. Glaciol. 30, 199-211.

Fridrich, C.J., DeWitt, E., Bryant, B., Richard, S., Smith, R.P., 1998. Geologic Map of the Collegiate Peaks Wilderness Area and the Grizzly Peak Caldera, Sawatch Range, central Colorado. U.S. Geol. Surv. Misc. Investigation Map I-2565.

Gosse J.C., Stone, J.O., 2001. Terrestrial cosmogenic nuclide methods passing milestones toward paleo-altimetry: EOS (Transactions, American Geophysical Union) 82, 82, 86, 89. 
Gosse, J.C., Phillips, F.M., 2001. Terrestrial in-situ cosmogenic nuclides: theory and application: Quat. Sci. Rev. 20, 1475-1560.

Gosse, J.C., Klein, J., Evenson, E.B., Lawn, B., Middleton, R., 1995. Beryllium-10 dating of the duration and retreat of the last Pinedale glacial sequence. Science 268, 1329-1333.

Hock, R., 1999. A distributed temperature-index ice- and snowmelt model including potential direct solar radiation. J. Glaciol. 45, 101-111.

Hostetler, S.W., Clark, P.U., 1997. Climatic controls of western U.S. glaciers at the last glacial maximum. Quat. Sci. Rev. 16, 505-511.

Jóhannesson, T.O., Siggurdsson, O., Laumann, T., Kennett, M., 1995. Degree-day glacier mass balance modelling with applications to glaciers in Iceland, Norway, and Greenland. J. Glaciol. 41, 345-358.

Lachniet, M.S., Seltzer, G.O., 2002. Late Quaternary glaciation of Costa Rica. Geol. Soc. Amer. Bull 114, 547-558.

Leonard, E.M., 1984. Late Pleistocene equilibrium-line altitudes and modern snow accumulation patterns, San Juan Mountains, Colorado, U.S.A. Arct. Alp. Res. 16, 65-76.

Leonard, E.M., 1989. Climate change in Colorado Rocky Mountains: estimates based on modern climate at late Pleistocene equilibrium-lines. Arct. Alp. Res. 21, 245-255.

Little, R.J., Rubin, D., 1987. Statistical Analysis with Missing Data. J. Wiley and Sons, New York.

Maher, L.J., 1972. Absolute pollen diagram of Redrock Lake, Boulder County, Colorado. Quat. Res. 2, 531-553.

Markgraf, V., Scott, L., 1981. Lower timberline in central Colorado during the past 15,000 yr. Geol. 9, 231-234.

Meier, M.F., Post A.S., 1962. Recent variations in mass net budgets of glaciers in western North America. Int. Assoc. Hydro. Sci. Pub. 58, 63-77.

Meierding, T.C., 1982. Late Pleistocene glacial equilibrium-line altitudes in the Colorado Front Range: a comparison of methods. Quat. Res. 18, 289-310.

Nesje, A., 1992. Topographical effects on the equilibrium-line altitude on glaciers. GeoJournal 27, 383-91.

Nesje, A., Dahl, S.O., 1991. Holocene glacier variations of Blåisen, Hardangerjøkulen, central southern Norway. Quat. Res. 35, 25-40.

Ohmura, A., Kasser, P., Funk, M., 1992. Climate at the equilibrium line of glaciers. J. Glaciol. $38,397-411$.

Paterson, W.S.B., 1994. The Physics of Glaciers. Pergamon Press, Oxford.

Phillips, F.M., Zreda, M.G., Gosse, J.C., Klein, J., Evenson, E.B., Hall, R.D., Chadwick, O.A., Sharma, P., 1997. Cosmogenic ${ }^{36} \mathrm{Cl}$ and ${ }^{10} \mathrm{Be}$ ages of Quaternary glacial and fluvial deposits of the Wind River Range, Wyoming. Geol. Soc. Amer. Bull. 109, 1453-1463.

Pierce, K.L., 1979. History and dynamics of glaciation in the northern Yellowstone National Park area. U.S. Geol. Surv. Prof. Pap. 729-F, 90 pp.

Porter, S.C., 1975. Equilibrium line altitudes of late Quaternary glaciers in the Southern Alps, New Zealand. Quat. Res. 5, 27-47.

Sharp, W.D., Ludwig, K.R., Chadwick, O.A., Amundson, R., Glaser, L.L., 2003. Dating fluvial terraces by ${ }^{230} \mathrm{Th} / \mathrm{U}$ on pedogenic carbonate, Wind River Basin, Wyoming. Quat. Res. 59, 139-150.

Short, S.K., Elias, S.A., 1987, New pollen and beetle analyses at the Mary Jane site, Colorado: evidence for late glacial tundra conditions. Geol. Soc. Amer. Bull. 98, 540-548. 
Stuiver, M., Reimer, P. J., 1993. Extended ${ }^{14} \mathrm{C}$ database and revised CALIB 5.0.1 radiocarbon calibration program, Radiocarbon 35, 215-230.

Thompson, R.S., Whitlock, C., Bartlein. P.J., Harrison, S.P., Spalding, W.G., 1993. Climatic changes in the western United States since 18,000 yr B.P. In Wright, H.E., Kutzbach, J.E., Webb, T., III, (Eds.), Global Climates since the Last Glacial Maximum. Univ. Minnesota Press, Minneapolis, MN, 468-513.

Tweto, O. 1983. Geologic sections across Colorado. U.S. Geol. Surv. Misc. Investigation Series Map I-1416.

Tweto, O., 1987. Rock units of the Precambrian basement in Colorado. U.S. Geol. Surv. Prof. Paper 1321-A.

Tweto, O., Moench, R.H., Reed, J.C., 1978. Geologic map of the Leadville $1^{\circ}$ x $2^{\circ}$ Quadrangle, northeastern Colorado. U.S. Geol. Surv. Misc. Investigation Series Map I-999.

Torsnes, I., Rye, N., Nesje, A., 1993. Modern and Little Ice Age equilibrium-line altitudes on outlet valley glaciers from Jostedalsbreen, western Norway: an evaluation of different approaches to their calculation. Arct. Alp. Res. 25, 106-116.

Vierling, L.A., 1998. Palynological evidence for late- and postglacial environmental change in central Colorado. Quat. Res. 49, 222-232. 
Table 1

Climate stations, climate data, and derived parameters used in this study

Station

Gunnison

Buena Vista

Crested Butte

Pitkin

Taylor Park (datum)

Park Cone (SNOTEL)

Independence Pass

Independence Pass (SNOTEL)

$\begin{array}{cc}\text { Elevation }(\mathrm{m}) & \text { Mean annual } \\ \text { temperature }\left({ }^{\circ} \mathrm{C}\right)\end{array}$

Mean annual precipitation $(\mathrm{cm})$
Amplitude of
2325

2432

2704

2804

2807

2926

3213

3231

$$
3.1
$$

6.6

1.5

0.8

$0.1\left(=\mathrm{T}_{\mathrm{a}}\right)$

$-0.6$

52.4

75.7

74.1
25.0

23.9

$62.2 *$

45.4

41.9

*Because of a pronounced precipitation difference in the Crested Butte region, this value wasn't used in the regression to define the vertical precipitation gradient. 
Table 2

Equilibrium-line altitudes (ELAs) for glaciers of the Taylor River Glacier Complex (TRGC) and paleoclimate inferred by degree-day modeling.

A. Simple accumulation-area ratio $(\mathrm{AAR}=0.65 \pm 0.05)$ approach.

Glacier

ELA $^{1}$

Taylor River Lobe

Spring Creek Lobe

Rocky Brook

Trail Creek

Bushwhack

TRGC

Means
$3400 \pm 50$

$3280 \pm 40$

$3395 \pm 10$

$3340 \pm 45$

$3275 \pm 35$

$3380 \pm 50$

$3340 \pm 60$
Implied $\Delta \mathrm{T}\left({ }^{\circ} \mathrm{C}\right)^{2}$

LGM precipitation scenario

$\Delta \mathrm{P}=1.0 \quad \Delta \mathrm{P}=1.25 \quad \Delta \mathrm{P}=0.75$

(modern) (25\% wetter) (25\% drier)

B. Steady-state mass balance approach.

Glacier

$$
\begin{array}{r}
\Delta \mathrm{P}=1.0 \\
\text { (modern) }
\end{array}
$$

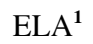

(m) $\Delta \mathrm{T}$ Equivalent $\left({ }^{\circ} \mathrm{C}\right)$

Taylor River Lobe 3450

Spring Creek Lobe 3365

Rocky Brook

Trail Creek

Bushwhack

Means$$
-6.7
$$

0.60

$\begin{array}{ll}-7.4 & 0.55\end{array}$

3450

$-6.7$

0.43

3400

$-7.1$

0.58

3350

$-7.5$

0.55

$3405 \pm 45 \quad-7.1 \pm 0.4 \quad 0.56 \pm 0.04$
LGM precipitation scenario

$$
\begin{gathered}
\Delta \mathrm{P}=1.25 \\
\text { (wetter) }
\end{gathered}
$$

$\Delta \mathrm{P}=0.75$

(drier)

ELA $^{1}$

(m)

$\Delta \mathrm{T} \quad$ Equivalent

required $^{2} \quad \mathrm{AAR}$ $\left({ }^{\circ} \mathrm{C}\right)$

AAR

ELA $^{1}$

(m)

$\Delta \mathrm{T} \quad$ Equivalent required $^{2} \quad$ AAR

$\begin{array}{lll}3460 & -6.3 & 0.58\end{array}$

3430 $\left({ }^{\circ} \mathrm{C}\right)$

$\begin{array}{lll}3375 & -7.0 & 0.53\end{array}$

3340

$-7.2$

0.62

3445

$-6.4 \quad 0.46$

3440

$-7.9$

0.57

3410

$-6.7$

0.57

3390

$-7.1$

0.47

3350

$-7.2 \quad 0.55$

3340

$-7.5$

0.60

$\begin{array}{ll}-7.9 & 0.57\end{array}$

${ }^{1}$ ELAs are reported to the nearest $5 \mathrm{~m}$.

${ }^{2}$ Temperatures are reported to the nearest $0.1{ }^{\circ} \mathrm{C}$. 


\section{Figure Captions}

Figure 1. Location map of the study area and the climate stations from which data were used in the modeling.

Figure 2. Extent of ice during the last glacial maximum within the Taylor River drainage. Glaciers marked with an asterisk are those for which Brugger and Goldstein (1999) estimated ELAs. Inset shows the locations of boulders sampled for cosmogenic surface-exposure ages (zero-erosion ages shown). A few very small ice masses are omitted for clarity.

Figure 3. Reconstruction of the Taylor River Glacier Complex during the last glacial maximum (LGM).

Figure 4. Photos of glaciated upland surfaces. (a) Small scour basins and riegels in the Mysterious upland. Headwalls are not much higher than what can be seen here. View is to the east. (b) Transverse rock bars near ice divide in Bowman upland. View is to the west. (c) Southeastward-looking view of trough in broad interfluve of the Eyre-Italian upland. Ice flowing in trough merged with northeastwardly (to the left) flowing ice in the main Taylor valley in the middle ground.

Figure 5. Area-altitude distributions and derived equilibrium-line altitudes (ELAs) for (a-e) individual glaciers of the Taylor River Glacier Complex and (f) the entire complex. Total area (in $\mathrm{km}^{2}$ ) is given for each glacier. Note differences in vertical scales.

Figure 6. Comparison of simulated and observed evolution of the modern snowpack at (a) Independence Pass and (b) Park Cone. Note difference in vertical scales. Estimated modern equilibrium-line altitudes in the study area using climate $(\mathrm{T}=$ temperature, $\mathrm{P}=$ precipitation $)$ at the ELA of modern glaciers as an analog and the degree-day model (DDM).

Figure 7. Examples of specific net mass-balance curves generated by the degree-day model that yield an equilibrium-line altitude of $3340 \mathrm{~m}$ under LGM climates in which total precipitation was similar to, slightly greater than, or slightly less than modern climate.

Figure 8. Equilibrium-line altitudes (contoured in intervals of $50 \mathrm{~m}$ ) derived from degree-day model as a function of mean summer temperature depression and precipitation (expressed as a fraction (percent) change over modern, modern $=1.0(100 \%)$ ). The emboldened contour labeled 3340 is the mean of LGM ELAs based on the AAR method. (The $3350 \mathrm{~m}$ contour is omitted for clarity.) 
FIGURE 1

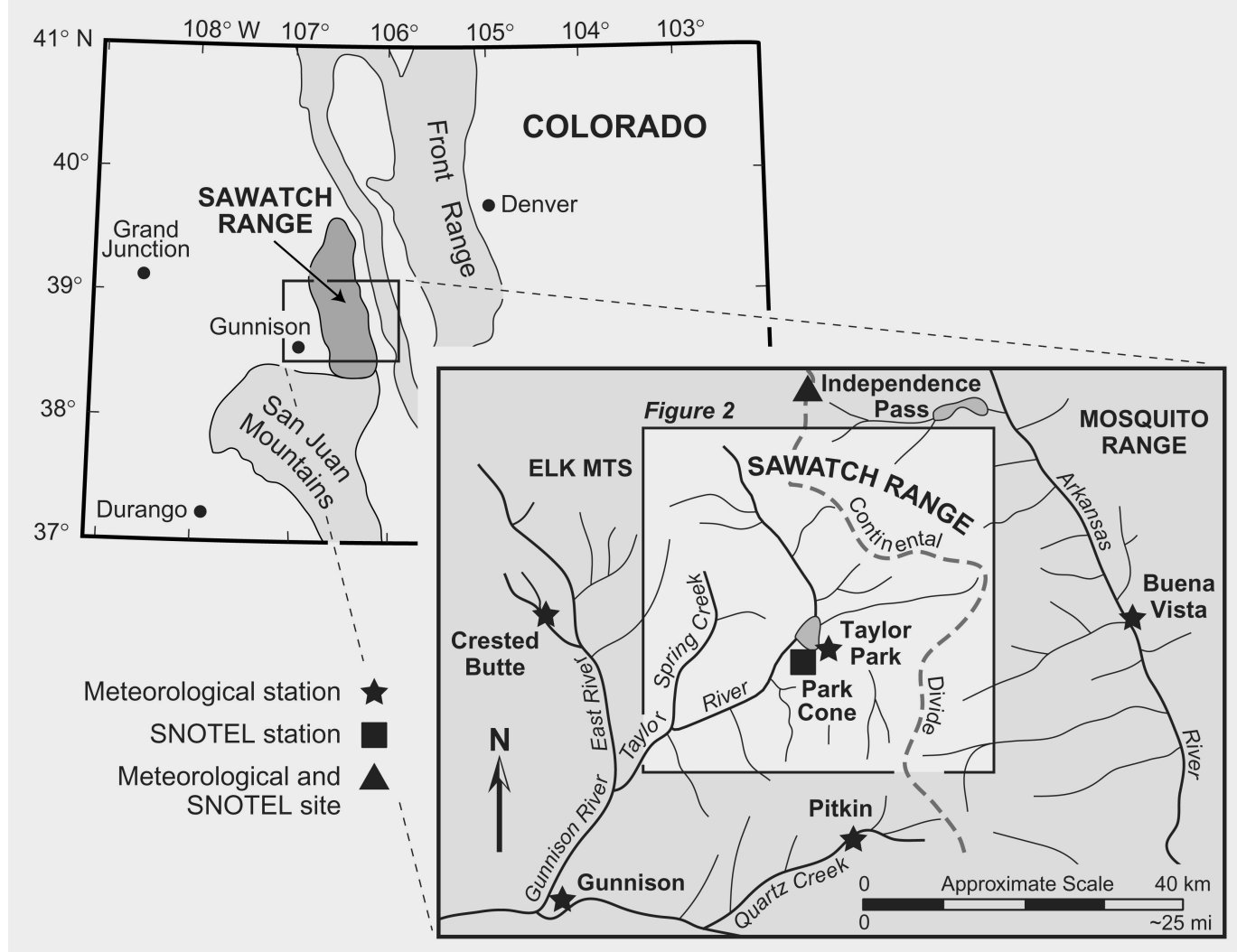


FIGURE 2

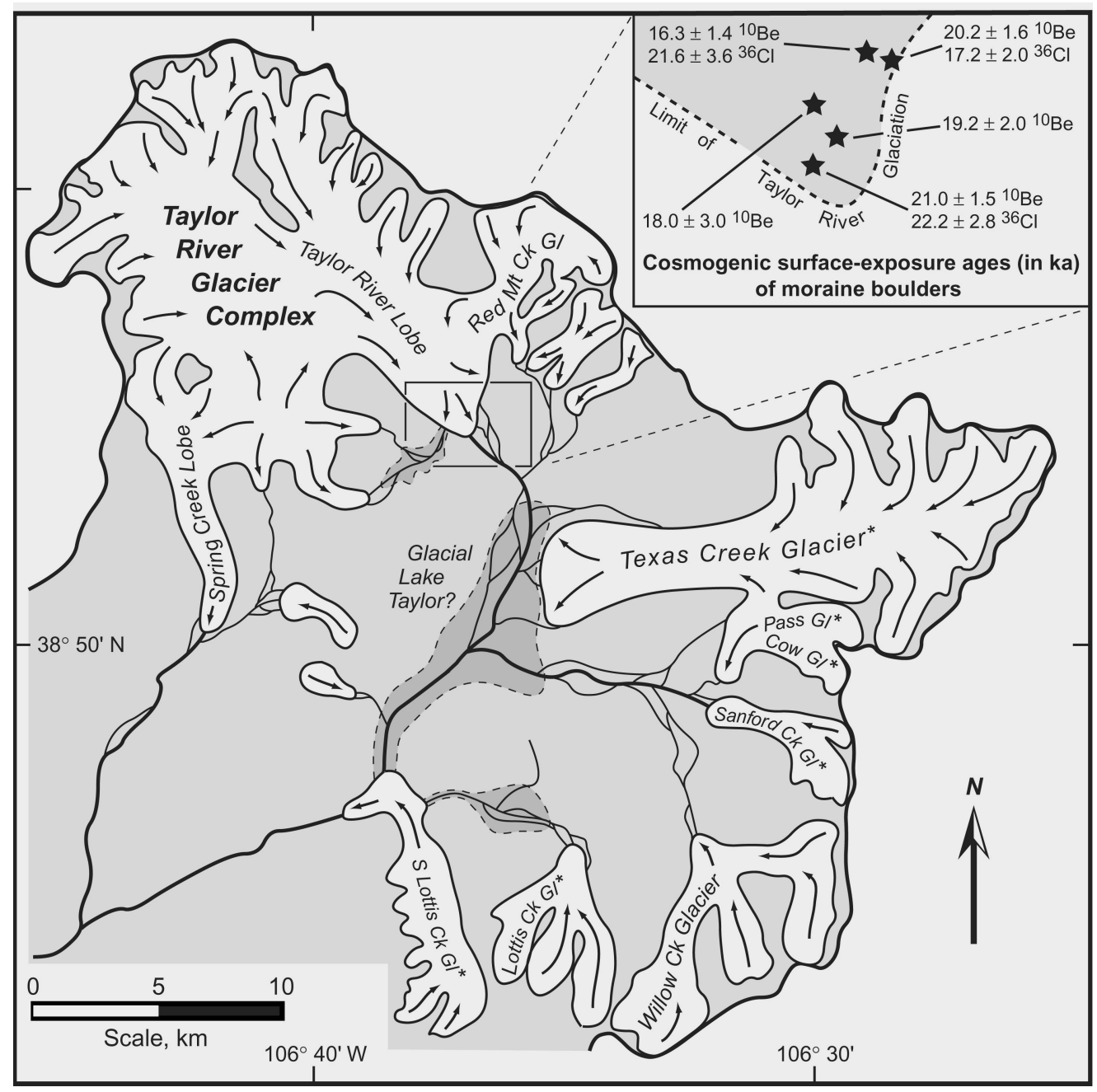


FIGURE 3

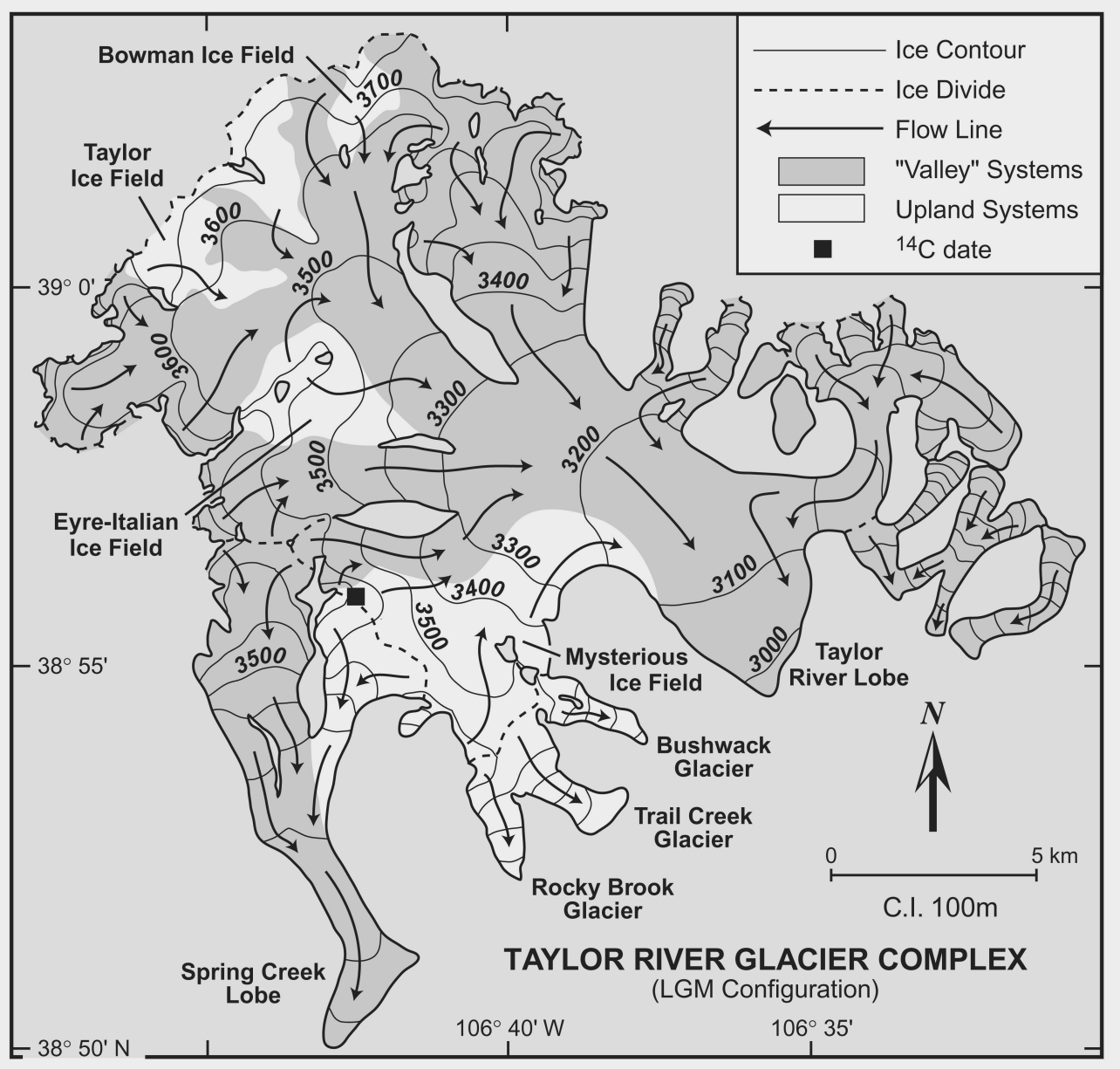


FIGURE 4
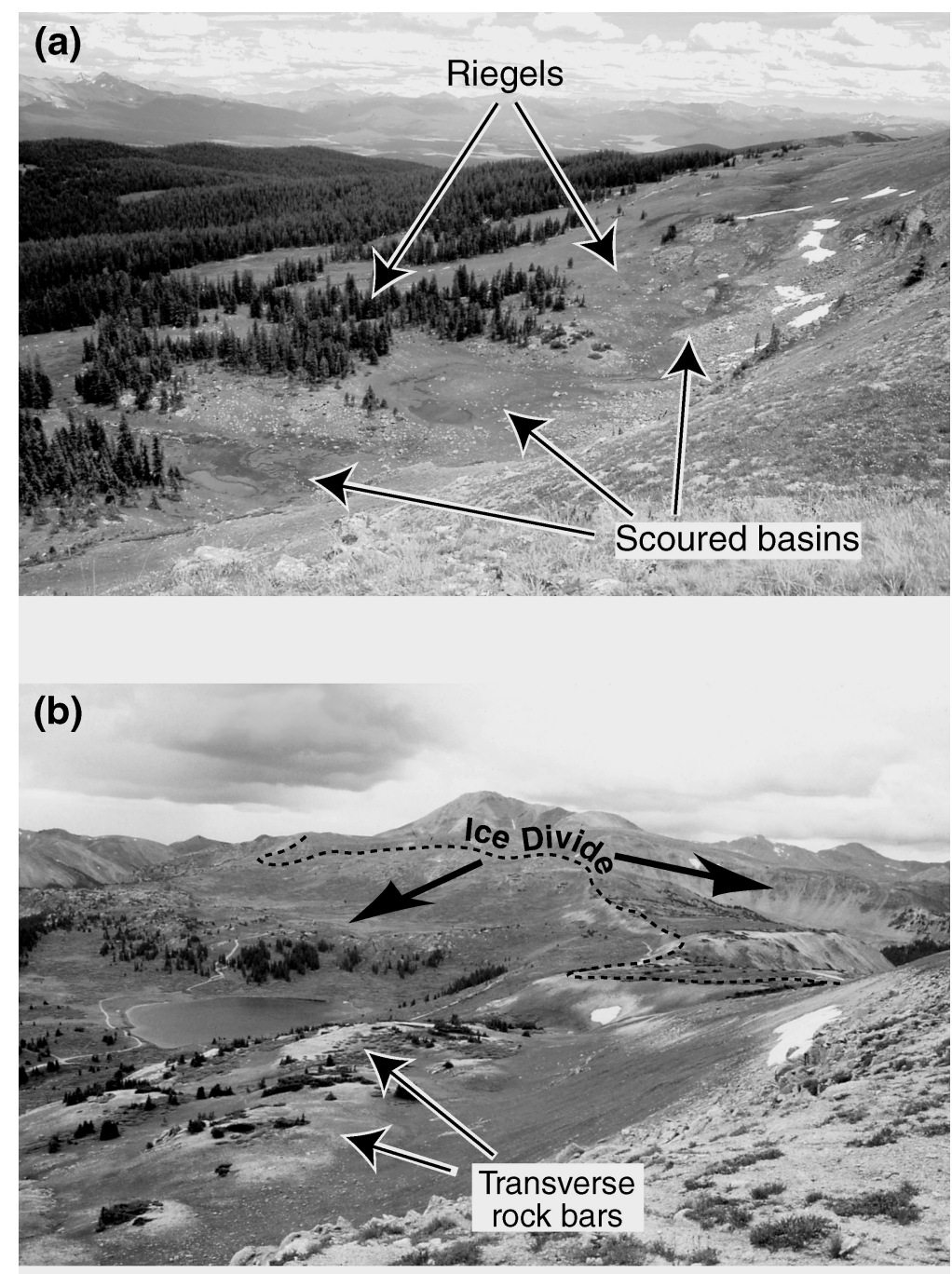

(c)

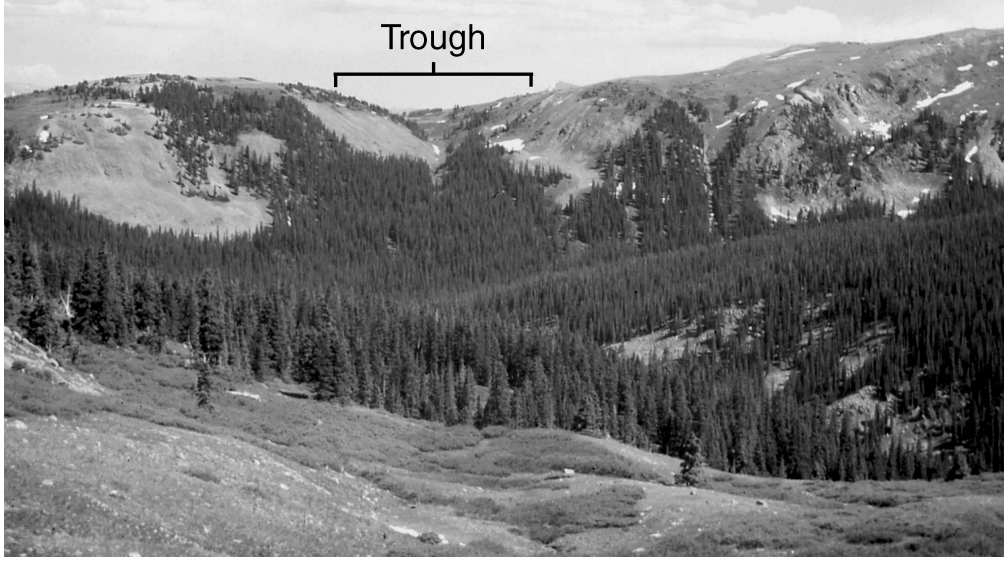




\section{FIGURE 5}

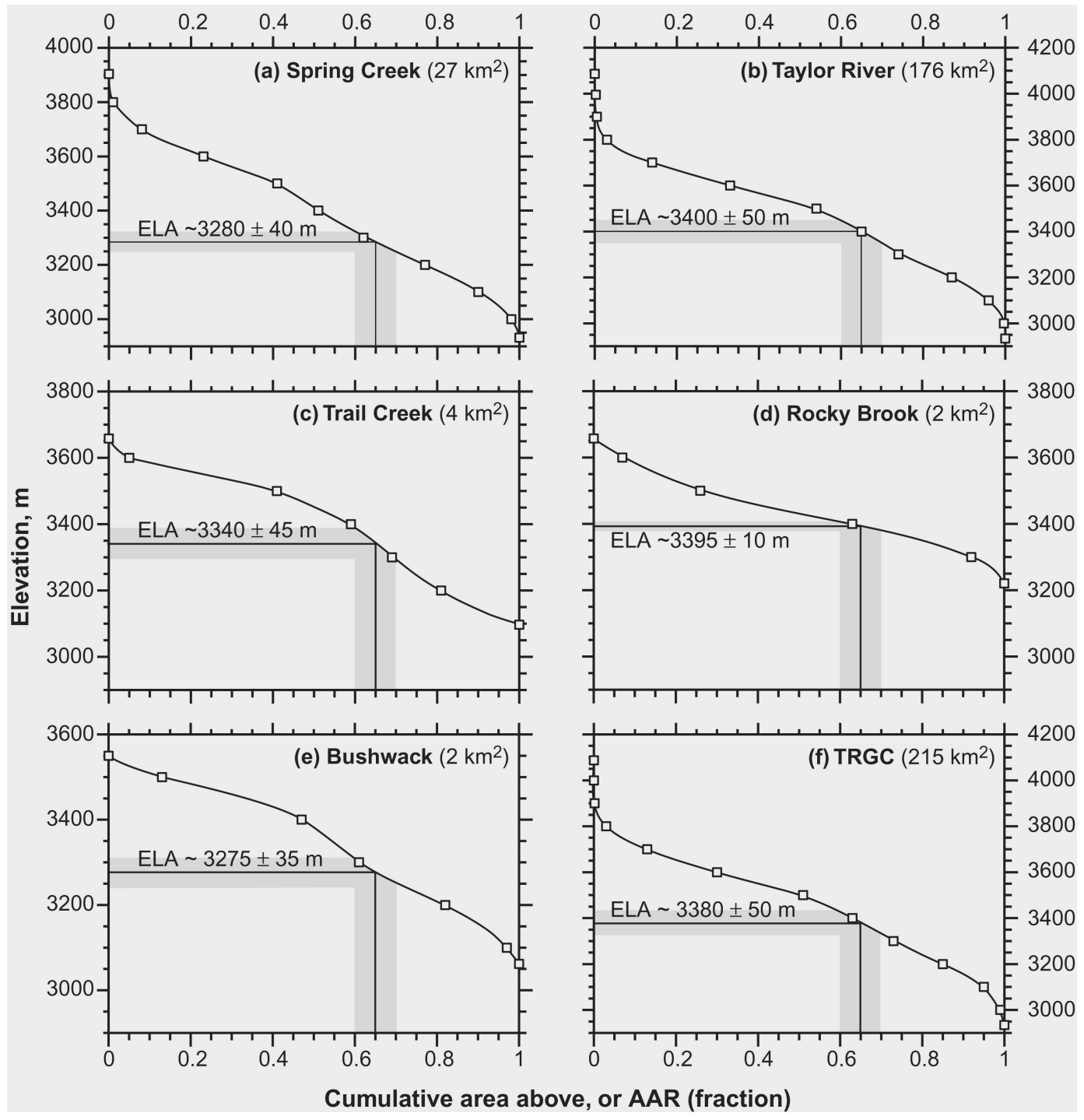


FIGURE 6

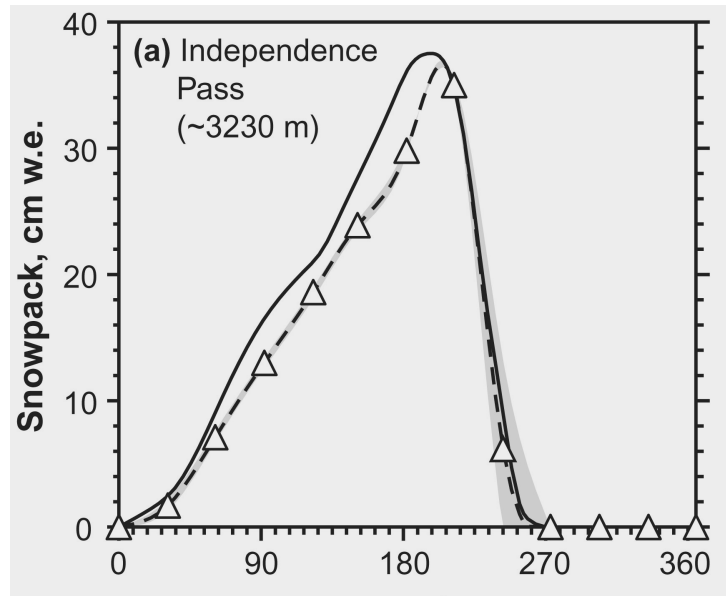

- Observed snowpack $-\Delta-\cdot$ Modeled snowpack
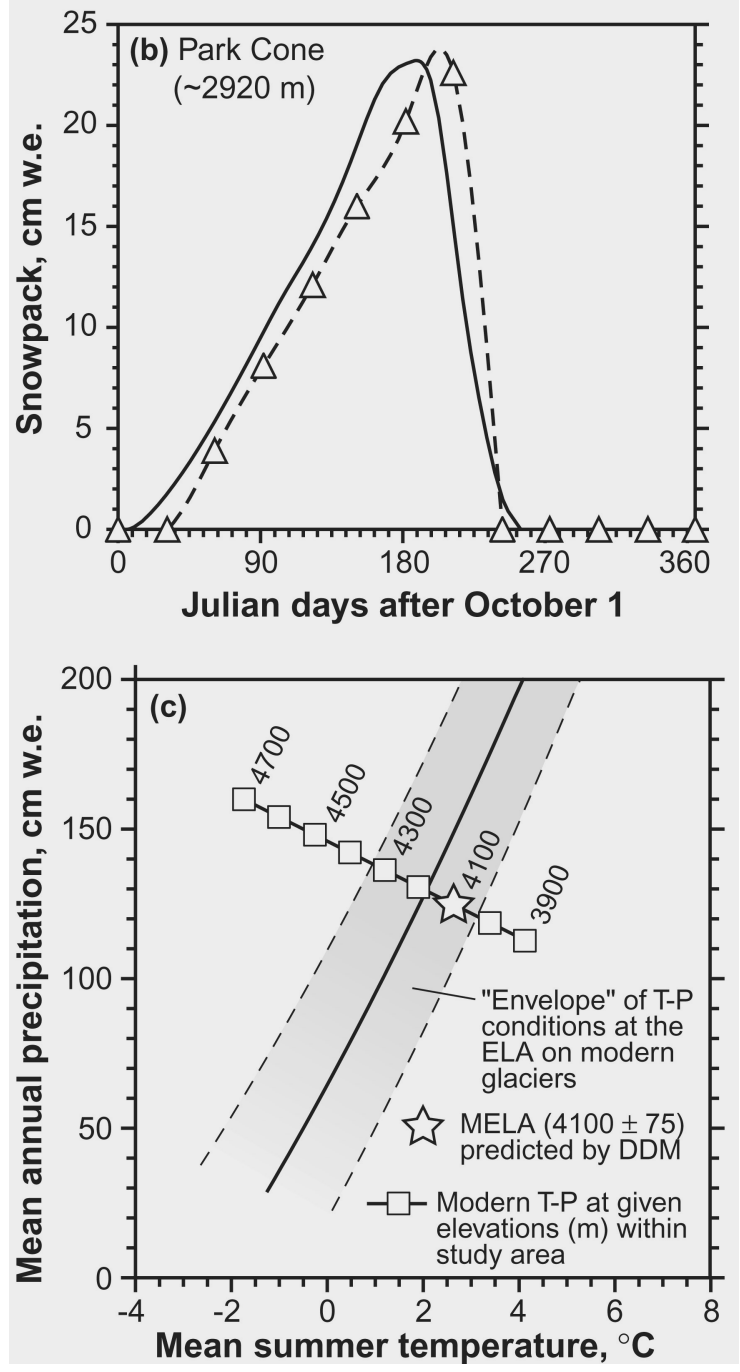
FIGURE 7

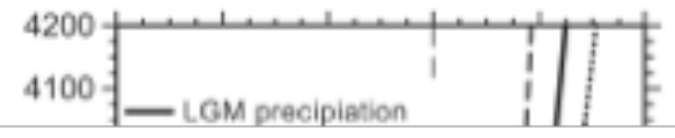




\section{FIGURE 8}

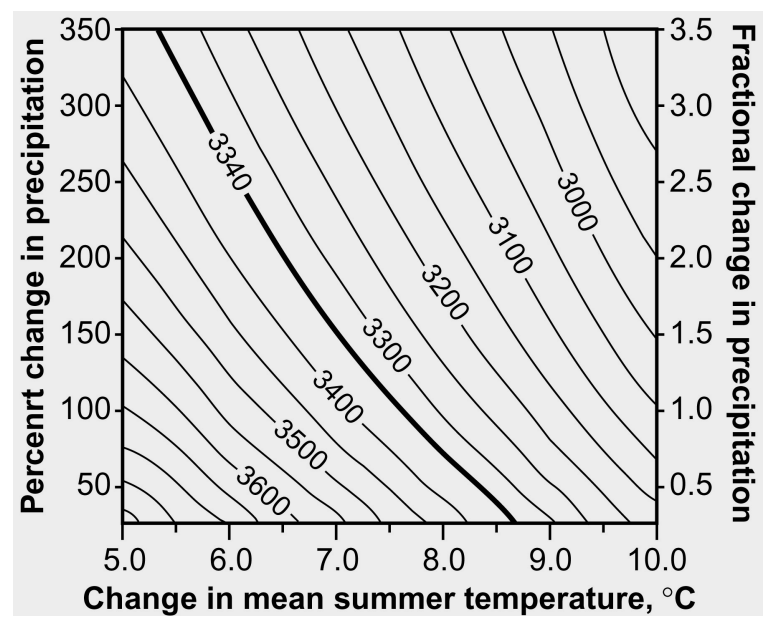

